\title{
5. A Kantian Responds to Santayana
}

\author{
Dr. Samuel J.M. Kahn \\ Assistant Professor of Philosophy \\ Indiana University-Purdue University, Indianapolis \\ United States \\ ORCID iD: http://orcid.org/0000-0001-6597-7646 \\ Web-address: http://liberalarts.iupui.edu/directory/bio/kahnsa \\ E-Mail: sjmkahn@gmail.com/kahnsa@iupui.edu
}

\section{Abstract:}

In this paper, I have argued that whatever might be said about his attack on other German philosophers, Santayana's attack on Kant, despite its subtlety, its force and its intelligence, is fundamentally misguided. Teasing out where Santayana's attack rests on misunderstandings of Kant's philosophy is a useful exercise: it is useful for Kantians, for it gives us a chance to show Kant at his best; it is useful for Santayana scholars, for it reminds us that Santayana, for all his brilliance, was not infallible; and it is useful more generally, for the mistakes Santayana makes about Kant are, perhaps in part because of Santayana's well-deservedly wide influence, still prevalent today.

\section{Keywords:}

Kant; Santayana; The German Mind: a philosophical diagnosis; German philosophy. 


\section{A Kantian Responds to Santayana}

\section{Introduction}

In The German Mind: a philosophical diagnosis, Santayana launches an extended attack on Kant and, indeed, German philosophy more generally. This attack centers on the concept of egotism. At the broadest level, the idea behind Santayana's attack is that egotism is a bad thing --- perhaps the worst thing in Santayana's eyes --- and it is something of which Kant and other German philosophers are guilty. But what exactly is egotism? Santayana gives three definitions in the course of his book:

1. "[Egotism is]... subjectivity in thought and willfulness in morals."

2. "Egotism... [mistakenly] assumes, if it does not assert, that the source of one's being and power lies in oneself, that will and logic are by right omnipotent, and that nothing should control the mind or the conscience itself." iii

3. "Egotism is subjectivism become proud of itself and proclaiming itself absolute."iv

The point of these definitions seems to be that egotism involves the rejection of any external standards. In epistemology, egotism seems to be taking one's own opinions for the True; in ethics, it seems to be taking one's own desires for the Good. One needs not to be a Platonist to see how this might lead one astray.

In this paper, I argue that whatever might be said about his attack on other German philosophers, Santayana's attack on Kant, despite its subtlety, its force and its intelligence, is fundamentally misguided. Teasing out where Santayana's attack rests on misunderstandings of Kant's philosophy is a useful exercise: it is useful for Kantians, for it gives us a chance to show Kant at his best; it is useful for Santayana scholars, for it reminds us that Santayana, for all his brilliance, was not infallible; and it is useful more generally, for the mistakes Santayana makes about Kant are, perhaps in part because of Santayana's well-deservedly wide influence, still prevalent today.

Santayana's attack on Kant is multi-pronged. He takes on transcendentalism generally and Kant's theory of knowledge; he takes on the role of inclinations and moral worth in Kant's ethics; he takes on Kant's doctrine of the practical postulates; and he (general) attacks on the Categorical Imperative. In what follows, I shall say something about each of these subjects in turn. 


\section{Transcendentalism and Kant's theory of knowledge}

Santayana's attack on transcendentalism and Kant's theory of knowledge are basically the same: both, according to him, are too subjective. For example, Santayana makes the following remarks about transcendentalism:

To take what views we will of things, if things will barely suffer us to take them, and then to declare that the things are mere terms in the views of them --- that is transcendentalism. ${ }^{v}$

This passage is difficult to unpack, but I think Santayana is saying something like the following: there are different ways of accounting for the facts in any given situation. An emerald might be green. But it also might be grue. Either of these could be true given our experiences. But there is some other way to evaluate these competing accounts, perhaps by appeal to simplicity or something like that. Transcendentalism involves throwing this other method of evaluation away and simply subscribing to the view that one wants provided that it accounts for the facts. The final step in transcendentalism according to this quotation is to declare that those facts are merely ideal, thoughts of the mind à la Berkeley.

Santayana says something similar here:

Earth and Heaven, God and my fellow men are mere expressions of my will, and if they were anything more, I could not now be alive to their presence. With that conclusion transcendentalism is complete. ${ }^{\mathrm{vi}}$

In this passage, Santayana is saying that transcendentalism involves the claim that subjects are aware only of manifestations of their own wills: transcendentalism and solipsism as embodied in subjective idealism go hand-in-hand. That said, to be fair to Santayana, it should be noted that in this passage he seems to be saying that this is the logical conclusion of transcendentalism: that is, if the proponents of transcendentalism followed out their doctrines to full, logical completion, they inevitably would reach subjective idealism.

Now there might be some German philosophers for whom this kind of criticism rings true. Schopenhauer springs to mind, among others. But Kant is not one of them. The word 'transcendental' has a very circumscribed use in Kant, and I shall say a few things about the two main uses of it: transcendental arguments and transcendental idealism.

A transcendental argument for Kant involves looking at what is presupposed by experience. That is, Kant takes our everyday experience of objects and our common sense claims about knowledge of these objects as a starting point: a transcendental argument is then used in order to adduce what must be true given that we have these experiences of objects and that we have knowledge of these objects. Kant is trying to determine the conditions of experience. There is nothing solipsistic here, nor is there anything that involves foisting an unlikely view of things on reality. Quite 
the contrary: Kant looks to other fields, fields like logic in order to understand what is involved in a judgment, and fields like Newtonian physics in order to understand what is involved in cognizing objects. Kant saw that Newtonian physics presuppose that space is Euclidean and he sought to justify this presupposition through claims about our perceptive faculties.

Since Kant's time, we have come to realize that there are non-Euclidean geometries and, further, that there are empirical grounds for taking the geometry of space to be non-Euclidean. But if there was a better justified view of things than Kant's in Kant's time, I do not see what it was. And although we might view parts of Kant's project in the transcendental aesthetic as unsuccessful now, now that we have advanced in our knowledge of physics and mathematics, if Kant's project was rotten at its core, if the way in which he was arguing was somehow fallacious, I do not see how. Kant's approach was groundbreaking, and we would do well to try to do something similar for our current scientific assumptions and practices. Regardless, the point is that if transcendentalism means making transcendental arguments of the kind Kant makes, then it does not involve accounting for the facts in unlikely ways or adopting theories that embody or entail a solipsistic view of the world.

Kant also uses the term 'transcendental' to refer to the philosophical view that he adopts in the Critique of Pure Reason: transcendental idealism. But according to transcendental idealism, every object I come in contact with on a daily basis, people, space, time, everything is empirically real. There is no solipsism in transcendental idealism: indeed, in the first division of the Transcendental Logic in the Critique of Pure Reason Kant famously gives a refutation of idealism. In this ingenious argument, Kant tries to prove the reality of external objects, arguing that self-consciousness would be impossible were it not for objects existing in space. The take home message here is that if transcendentalism means adhering to Kant's version of transcendental idealism, then transcendentalism does not involve foisting unlikely theories onto observations and it explicitly distances itself from subjective idealism.

But the core of Santayana's attack on Kant's theory of knowledge is that it allows one to believe what one will. We saw this above while discussing what Santayana means by 'egotism'. It came up again in the passages about transcendentalism. And it is sprinkled in other passages, too. For example, at 34p2 Santayana remarks on Kant's “... radical subjectification of knowledge", and at 61p2 Santayana again comments on "... the subjectivity which he [viz., Kant] attributed to knowledge."

I am not sure what motivates Santayana to say this, but I think that a quick discussion of section three of the Canon of Pure Reason (A820/B848) vii will suffice to allay any fears we might have on Kant's account. In this section Kant discusses the difference between having an opinion, believing and knowing. All three of these involve judging something to be true, but beyond that they differ. To have an opinion of something is to believe it to be true but at the same time to be conscious that one's grounds for belief are neither objectively nor subjectively sufficient. If something is held to be true on grounds that are subjectively but not objectively sufficient, then it is a belief. If something is held to be true on subjectively and objectively sufficient grounds, then it is knowledge. Now I cannot discuss at length what would count as subjectively sufficient grounds for believing sometiog Vol 3 No 1 (2015)

ISSUE - March

ISSN 2347-6869 (E) \& ISSN 2347-2146 (P)

A Kantian Responds to Santayana by Dr. Samuel J.M. Kahn Page No. 66-79 
But I bring this section up to make a simple point: having objectively sufficient grounds for believing something involves, on Kant's account, talking and arguing with others to see whether they already have or can be made through rational discourse to have the same judgment.

So Kant gives a criterion for knowledge: believing at will does not pass muster for Kant. "Merely" fitting the data might suffice for opinion, but it is unclear whether it would suffice for belief, and it certainly would not suffice for knowledge. Kant was about as far as he could be from subjectivism about knowledge. So this part of Santayana's criticism, anyway, is unfounded. But as noted above, Santayana's attack is multi-pronged, and the greater part of it deals with Kant's ethics. It is to that part of Santayana's attack that I now turn.

\section{The role of inclinations and moral worth in Kant's ethics}

Santayana's attack on the role of inclinations and moral worth in Kant's ethics can be found principally in two passages. The first is the following:

In Kant, who in this matter followed Calvin, the independence of the movement of nature, both within and without the soul, and the ideal of right was exaggerated into an opposition... Human nature was totally depraved and incapable of the least merit, nor had it any power of itself to become righteous. Its amiable spontaneous virtues, having but a natural motive, were splendid vices. Moral worth began only when the will, transformed at the touch of unmerited grace, surrendered every impulse in overwhelming reverence for the divine law. viii

There are two claims in this passage that I would like to focus on: there is a claim about moral worth and there is a claim about the role of inclinations in Kant's ethics.

With regard to moral worth, Santayana claims that, for Kant, moral worth begins only when the will surrenders every impulse "in overwhelming reverence" for the moral law. The idea is that Kant thinks that an agent's actions have moral worth if, but only if, s/he is acting exclusively out of respect for the moral law rather than out of, say, love or natural sympathy. This is true as far as it goes. In part I of the Groundwork for a Metaphysics of Morals, Kant describes a man who, lost in his own grief and therefore unable to commiserate with the suffering of others, "tears himself out of this deadly insensibility" to promote the happiness of someone else. ${ }^{\text {ix }}$ Kant remarks that it is only now that he is acting from duty that this man's actions have moral worth; if he previously had promoted others' happiness out of sympathy or inclination, his actions would deserve praise and encouragement but not esteem.

The trouble is that this does not go very far, not nearly as far as some people, Santayana among them, I suspect, try to make it go. There are three general misconceptions that need to be 
corrected here. First, the concept of moral worth is not a particularly important one for Kant. He uses it in part I of the Groundwork for a Metaphysics of Morals as an intuition pump --- if only he had known how counterintuitive many would find his remarks: he could have spared himself much unwarranted criticism by leaving them out --- but it is hardly ever again mentioned either in the Groundwork for a Metaphysics of Morals or in any of his other major ethical works, including the Critique of Practical Reason, the Metaphysics of Morals and the Religion within the Boundaries of mere Reason. If Kant's concept of moral worth were to fall, very little from the edifice of Kant's ethics would go with it. Criticizing Kant's concept of moral worth and expecting Kant's ethics to fall thereby is a bit like tearing down a poster on the ground floor of the Empire State Building and expecting the entire building to crumble.

Second, Kant does not think of moral worth as something that ought to be maximized. He does not think that agents ought to put themselves in situations in which they have no inclination to do their duties or, more, in which they have to overcome temptations from inclination to do their duties. An analogy here might be instructive: Suppose you see a house burning down in a fire, and you watch someone running into that house and performing a daring rescue. Now suppose that you admire this person's courage and fortitude. Does it follow that you should begin setting houses on fire, perhaps making sure before you do so that the inhabitants are at home, in order to maximize the number of such daring rescues? No, clearly not. Alternatively, suppose that you believe keeping your promises is a good thing. Does it follow that you should go around making promises all the time in order to maximize the number of kept promises? Again, clearly not. In the first case, it follows that if there is a fire and someone performs a daring rescue, you will admire that person; in the second case, it follows that if you make a promise, you will view it as a good thing to keep it. Nothing more. I suggest that Kant was saying something similar about moral worth. He claims that we esteem a man when he tears himself out of his own insensibility to aid his friend in a way that we do not, when he aids his friend from sheer joie de vivre. But what follows? Only that if such a situation arises, we esteem a person in a certain way, not that we ought to try to maximize the instances in which we are able to esteem someone in that way.

The third general misconception about Kant's notion of moral worth is perhaps the most serious, and it also serves conveniently as a segue into Santayana's claim about the role of inclinations in Kant's ethics. Popular misconceptions notwithstanding, Kant's notion of moral worth does not require the mortification of the inclinations. This might have been inferred from my remarks about the beneficent man in part I of the Groundwork for a Metaphysics of Morals: Kant tells us that this man pulls himself out of insensibility --- not out of misanthropy. Let me explain.

For Kant, an action has moral worth only if it is performed from duty. But this does not mean that an agent can have no other inducement to perform the action; it means that even if the agent does have other inducements to perform the action, in a nearby possible world in which s/he does not have such inducements, $\mathrm{s} /$ he will perform the action. ${ }^{\mathrm{x}}$ To summarize, moral worth is not a key concept for Kant; moral worth is not something that ought to be maximized; and moral worth does not require acting against one's inclinations.

Vol 3 No 1 (2015)

ISSUE - March

ISSN 2347-6869 (E) \& ISSN 2347-2146 (P)

A Kantian Responds to Santayana by Dr. Samuel J.M. Kahn Page No. 66-79 
This last point should go some way toward combating Santayana's claim about the role of inclinations in Kant. According to Santayana, Kant takes acting from natural sympathies or from inclination always to be a vice. ${ }^{\text {i }}$ But this cannot be based on what Kant says about moral worth: as we already have seen, although moral worth does require acting from duty rather than acting from natural sympathies or inclination, moral worth is not something to be maximized, and moral worth does not require acting against natural sympathies or inclination. Indeed, Kant goes so far as to say that doing one's duty from inclination, e.g., promoting the happiness of others from natural sympathy, deserves "praise and encouragement."xii

But more needs to be said here lest I be mistaken to have conceded too much. The importance of feelings, of the "spontaneous virtues" and of "natural motive" to Kant's account of virtue and acting rightly can be inferred from the importance he assigns to the feeling of respect and of practical love in the Groundwork for a Metaphysics of Morals. It is through the feeling of respect that the Categorical Imperative first motivates us.xii And in the Metaphysics of Morals, Kant goes on to argue that there are three kinds of feeling that are essential for moral beings: the moral feeling, the “... susceptibility to feel pleasure or displeasure merely from being aware that our actions are consistent with or contrary to the law of duty"; xiv the love of human beings; and respect.xv

In point of fact, as if foreseeing that somebody would say something like what Santayana says in the passage I quoted above, Kant makes the following argument in the Religion within the Boundaries of mere Reason:

... the first really good thing that a human being can do is to extricate himself from an evil which is to be sought not in his inclinations but in his perverted maxims, and hence in freedom itself. Those inclinations only make more difficult the execution of the good maxims opposing them; whereas genuine evil consists in our will not to resist the inclinations when they invite transgression, and this disposition is the really true enemy. The inclinations are opponents of the basic principles only in general (be these principles good or bad), and to this extent that high-minded principle of morality [of the Stoics] is beneficial as a preliminary exercise (the discipline of the inclinations in general) that renders the subject tractable at the hand of basic principles. But, to the extent that specific principles of moral goodness ought to be present yet, as maxims, are not, we must presuppose in the subject somebody else opposing them, in the struggle with which virtue must hold its own; without it all virtues, though indeed not splendid vices, as one Church Father has it, would certainly be splendid frailties, for through them rebellion is indeed often stilled, though never the rebel himself conquered and extirpated.xvi

In this passage, Kant confronts directly the kind of objection Santayana raises. He states explicitly and unequivocally that our natural virtues are not vices on his account.

Vol 3 No 1 (2015)

ISSUE - March

ISSN 2347-6869 (E) \& ISSN 2347-2146 (P)

A Kantian Responds to Santayana by Dr. Samuel J.M. Kahn Page No. 66-79 
Setting all of this aside, Santayana was onto something in his criticism of the role of the inclinations in Kant, for Kant does say that the natural virtues are splendid frailties. But here I think Kant is, in fact, on firm ground. Let me explain.

Imagine a judge who, having grown sympathetic with a criminal in some particular case, is called upon to give sentence when that criminal is declared guilty. The judge's eyes tear up and s/he hesitates for a moment: "what to do?" Or imagine a physician who, having specialized in ophthalmology, is present at an accident and must perform a life-saving operation on someone. Squeamish of blood and not liking to cause pain, s/he hesitates before pulling out the scalpel. Or imagine a teacher whose student has not turned in any homework assignments and managed to get a 0 on the final. Now suppose this teacher is a soft-ie --- does not like to fail people because life is hard. What should these people do? Follow their natural sympathies? When you, a good person inclined to help those in need, see a burglar struggling down the steps of the bank with a heavy load, should you help him/her?

I think the answer is clearly "no": the judge must sentence the criminal; the doctor must operate on the patient; the teacher must fail the student; and you should not help the burglar. These are cases where duty is hard, where duty conflicts with our natural sympathies, but where its clarion call is unambiguous, ennobling and, ultimately, healing. Tough love is tough not only for its subjects but for its practitioners, but it is love nonetheless, and not only its aim but its consequences are good. "Spare the rod and spoil the child" is not a command but a warning: even if you do not favor physical punishment, discipline is needed in one form or another.

I would like to say one last thing before I turn to Santayana's attack on Kant's doctrine of the practical postulates. At 62p2, Santayana makes the following remark:

Kant expressly repudiated as unworthy of a virtuous will any consideration of happiness, or of consequences, either to oneself or to others.

Santayana claims here that Kant repudiates any consideration of happiness, either of one's own happiness or the happiness of others, when it comes to virtue and goodness. But this is false. Kant tells us time and time again that we have a duty to promote the happiness of others, and he tells us time and time again that the only reason we do not have a duty to promote our own happiness is that we do so naturally. Consider, for example, the following representative passage from the Metaphysics of Morals;

I want everyone else to be benevolent to me (benevolentiam); hence I ought also to be benevolent toward everyone else. But since all others with the exception of myself would not be all, so that the maxim would not have within it the universality of a law, which is still necessary for imposing obligation, the law making benevolence a duty will include myself, as

Vol 3 No 1 (2015)

ISSUE - March

ISSN 2347-6869 (E) \& ISSN 2347-2146 (P)

A Kantian Responds to Santayana by Dr. Samuel J.M. Kahn Page No. 66-79 
an object of benevolence, in the command of practical reason. This does not mean that I am thereby under obligation to love myself (for this happens unavoidably, apart from any command, so there is no obligation to it); it means instead that law-giving reason, which includes the whole species (and so myself as well) in its idea of humanity as such, includes me as giving universal law along with all others in the duty of mutual benevolence, in accordance with the principle of equality, and permits you to be benevolent to yourself on the condition of your being benevolent to every other as well; for it is only in this way that your maxim (of beneficence) qualifies for a giving of universal law, the principle on which every law of duty is based. ${ }^{\text {vii }}$

I turn now to consideration of Santayana's criticism of Kant's doctrine of the practical postulates.

\section{Kant's doctrine of the practical postulates}

Kant's doctrine of the practical postulates is one of the less well-studied parts of his doctrine, and although many modern day Kantians tend to think that his most important ethical insights can be divorced from it, its importance to Kant can be inferred from the fact that it recurs throughout his corpus and his lectures, perhaps most notably in the Critique of Pure Reason, the Critique of Practical Reason and the Critique of the Power of Judgment. From this and from the fact that the arguments change in sometimes subtle and sometimes not-so-subtle ways in their various articulations, it also may be inferred that Kant struggled with these arguments, which were supposed to establish that we ought to believe in God, freedom and the immorality of the soul, for much of his post-1781 career. That said, the rough contour of these arguments stays pretty much the same throughout, and it will suffice for my purposes to have merely this contour in place.

Kant argues that the moral law commands us to promote the highest good, a world in which everyone is supremely virtuous and in which happiness is doled out in accordance with virtue. But in order to promote an end rationally, I must believe that the end is not merely logically possible (i.e., free of internal contradiction) but also really possible (i.e., that it has a ground in something existing). But the highest good is really possible only if there is a perfectly good, omnipotent, omniscient God, if we are free and if the soul is immortal. Therefore, if I am going to fulfill my moral duties, I must believe in the existence of a perfectly good, omnipotent, omniscient God, that I am free and that my soul is immortal. 
Santayana responds to this argument as follows:

A categorical imperative crying in the wilderness, a duty which nobody need listen to, or suffer for disregarding, seemed rather a forlorn authority. To save the face of absolute right another world seemed to be required, as in orthodox Christianity, in which it might be duly vindicated and obeyed.xviii

Santayana seems to be saying here that the point of the practical postulates is to give us a motive to follow the Categorical Imperative. Since (Because) the Categorical Imperative is a command of reason rather than a counsel of prudence, obeying it might lead to unhappiness and suffering and disobeying it might not. So the practical postulates are brought in: there is another world in which those who do follow the Categorical Imperative are rewarded and those who do not are punished, so prudence and morality coincide, after all, and there is, therefore, a prudential motive to follow the Categorical Imperative.

Now I want to say three things in response to this criticism of Kant's doctrine of the practical postulates. First, I think that Kant's doctrine of the practical postulates, whatever else its failings might be, should be given due credit for its novelty. Kant is unlike Anselm and Aquinas, unlike Descartes and Leibniz, unlike Plantinga and Behe: Kant does not argue on theoretical grounds that we ought to believe in God. Indeed, he argues that there can be no theoretical grounds for believing in God, and in the second half of the Critique of Pure Reason he attacks the traditional arguments for the existence of God. Kant's argument is based on practical considerations. The idea that one must believe that something is not merely logically but also really possible in order to pursue it rationally is intuitively plausible and deserves more reflection than it is usually given. But the point is that the only other B.K. (Before Kant) thinker of whom I am aware of, who makes an argument even remotely like this is Pascal; Pascal argues in the Pensées that (1) we can have no theoretical grounds for believing in God but (2) we do have prudential grounds for believing in God. The point I am trying to make is not a deep one. It is simply this: Kant's argument for the practical postulates is unique and interesting, and it contains some interesting insights that bear investigation.

The second thing I want to say speaks more directly to Santayana's criticism of Kant's argument. According to Santayana, Kant introduces the practical postulates in order to "save the face" of the Categorical Imperative. The idea seems to be that the practical postulates are needed in order to show that even if obeying the Categorical Imperative might mean sacrificing earthly happiness, doing so is nonetheless prudent, for disobeying the Categorical Imperative means sacrificing eternal happiness. In other words, according to Santayana Kant introduces the practical postulates in order to explain why the Categorical Imperative still rests on self-interested motives.

The trouble with this criticism is that it flips Kant's argument on its head. Kant does not argue that we ought to fulfill the commands of the moral law because we have independent reason to believe in the truth of the practical postulates. Kant's argument is that we ought to believe in the

Vol 3 No 1 (2015)

ISSUE - March

ISSN 2347-6869 (E) \& ISSN 2347-2146 (P)

A Kantian Responds to Santayana by Dr. Samuel J.M. Kahn Page No. 66-79

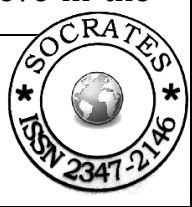


practical postulates because we ought to fulfill the commands of the moral law. Indeed, he argues that there is no such independent reason to believe in the truth of the practical postulates. Consideration of motives does not enter the picture. And given Kant's stark contrast between happiness and morality, happiness and worthiness to be happy, it is difficult to see how Kant coherently could have endorsed an argument of the type Santayana is attributing to him. To see this from another angle, consider again Kant's remarks about moral worth: if acting from prudential motives does not warrant moral worth, it makes no sense to bring in the practical postulates in order to provide a prudential motive for acting in accordance with the Categorical Imperative. So not only is this not what Kant does, but doing so would be to set himself at variance with himself.

The third and final thing I want to say here is about Kant's personal beliefs. At 58p3, Santayana says that Kant's handling of the practical postulates "... was only a laboured means of reestablishing the theology of Leibniz, in which Kant privately believed," and at 59p2, Santayana says of Kant that

He taught rather less than he secretly believed... Doubtless in his private capacity Kant hoped, if he did not believe, that God, free-will, and another life subsisted in fact, as every believer had hitherto supposed...

Santayana is making conjectures here about Kant's personal beliefs. In particular, Santayana is conjecturing that Kant believed in God and immortality of the soul. I am not sure what Santayana's grounds are for his conjectures, for he does not provide them. I point out merely that during Kant's life, he had a reputation as an atheist, and he is reported to have feared that he could lose his university position because of it.xix

\section{The subjectivity of the Categorical Imperative}

I would like to conclude by making some remarks about the supposed subjectivity of the Categorical Imperative. Santayana says that "[in Kant]... the most subjective of feelings, the feeling of what ought to be, legislates for the universe."xx This seems to be what is at the root of Santayana's complaint about Kant's egotism in ethics: as pointed out in the introduction, Santayana takes egotism to imply willfulness in morals.

It is certainly true, as I pointed out above in discussing the role of inclination in Kant's ethics, that feelings, like the feelings of respect and of love for human beings, play an important correlative role to the Categorical Imperative. But the important thing to note here is that they play a correlative role: these feelings inform the sensible side of morality. But good is fundamentally conceptual for Kant, and the Categorical Imperative is the rule of Reason with a capital ' $R$ '.

This should not be misunderstood. The idea is not that there is, for example, no room for culture in informing our duties within Kant's ethics. Similarly, the idea is not that there is no room for moral progress or that all agents at all times in all places are to be condemned and praised for exactly

Vol 3 No 1 (2015)

ISSUE - March

ISSN 2347-6869 (E) \& ISSN 2347-2146 (P)

A Kantian Responds to Santayana by Dr. Samuel J.M. Kahn Page No. 66-79

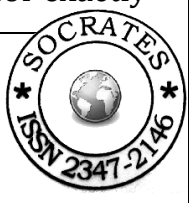


the same thing. Of course, there is one way of describing all bad acts on Kant's account: an action is impermissible if, and only if, it is not in accordance with the Categorical Imperative. But the point is that acknowledging the Categorical Imperative as the Supreme Law of Morality (at least as such a law would apply to imperfectly rational beings like us)- is consistent with the usual facts trotted out in favor of moral relativism.

To put this another way, Kant steers a course between the Scylla of cultural relativism and subjectivism on the one side and the Charybdis of an unchanging, monolithic ethical objectivism on the other. How does he do this? I only can make a brief suggestion here. Take the formula of humanity formulation of the Categorical Imperative; it instructs us to treat humanity always as an end and never merely as a means. But whether one's actions meet this criterion is a hermeneutical question: it is a question about the meaning of one's actions. And the meanings of one's actions are not determined strictly by one's intentions; they are fixed to some extent by one's culture and community in the same way as the meanings of words. One word might mean very different things in two different languages just as one action might mean very different things in two different cultures or communities. But there is a meaning, nonetheless, and this is what the formula of humanity is tracking.

So I would resist Santayana's attack on the Categorical Imperative. More than that, I would resist Santayana's insinuations in his post-script that the fanaticism of Nazi Germany was rooted in and can be traced back to Kant.xxi In point of fact, I would argue that in many cases it is only through Kant's ethics, especially as embodied in the formula of humanity, that we can make sense of why some actions, including those committed by the Nazis, are wrong. The idea that humanity has an inner worth --- that rational beings have dignity and that agents should be treated as ends in themselves regardless of race, creed or birth --- has deep roots in modern culture. It embodies the ideals by which many of us seek to govern ourselves. And it is the perennial battle cry against injustice around the world. 


\section{REFERENCES:}

i All SANTAYANA QUOTATIONS, UNLESS OTHERWISE INDiCATED, ARE TAKEN FROM THE 1968 APOLLO EDITION of The German Mind: A Philosophical diagnosis, ORiginally PUblished in 1916 Under the TITLE Egotism in German Philosophy. All Citations give PAge number Followed by the number of The PARAGRAPH ON THE PAGE FROM WHICH THE QUOTATION IS TAKEN.

ii IBIDEM, XIVP3.

iii IBIDEM, 169P1.

iv IBIDEM, 169P1-170P1.

v IBIDEM, 42P2.

vi IBIDEM, 40p1.

vii Citations to Kant will be to the Akademie Ausgabe by volume and page, except for the Critique of Pure Reason Where Citations Will uSE THE STANDARd A/B EDition PAgination. EnGLiSh QUOTATIONS WILL BE, UNLESS OTHERWISE INDICATED, FROM THE CAMBRIDGE EDITION OF THE WORKS OF Immanuel Kant, general editors Paul Guyer and Allen Wood (CAmbridge, 1992-).

viii IBIDEM, 57P1.

ix GMS, AA 04:398.

X MoRe CAN AND NEEDS TO BE SAID HERE, BUT I CANNOT DO SO NOW.

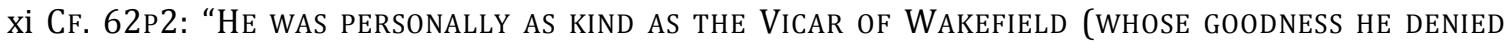
BECAUSE IT WAS NATURAL)..."

xii GMS, AA 04:399.

xiii GMS, AA 04:400-402.

xiv MDS, AA 06:399.

xv MDS, AA 06:401-403.

xvi RGV AA, 06:58N. 
xvii MdS, AA 06:451. CF. MdS, AA 06:393. For the DERIVATION OF A Similar DUty in the Critique of PRACTICAL REASON, SEE KPV, AA 05:34-35.

Xviii IBIDEM, 58P1.

Xix HERE I AM RELYING ON 318P1-2 OF KUEHN'S EXCELLENT 2001 BIOGRAPHY OF KANT. Xx IBIDEM, 62P1.

xxi SEE ESP. IBIDEM, 176P2-177P2.

\section{CITE THIS ARTICLE:}

\section{Citation Format APA}

Kahn, D. (2015). A Kantian responds to Santayana. S O C R A T E S, 3(1), 66-79. Retrieved from http://vrr.socratesjournal.com/index.php/socrates/article/view/121

For More Citation formats please visit:

http:// vwr.socratesjournal.com/index.php/socrates/rt/captureCite/ 12l/0 